\title{
ДЕЯКІ АСПЕКТИ ЮРИДИЧНОЇ ВІДПОВІДАЛЬНОСТІ ЗА ПОРУШЕННЯ АВТОРСЬКИХ І СУМІЖНИХ ПРАВ
}

\author{
Янішевська К. Д., Воронкова М. Ю.
}

у статті визначено види юридичної відповідальності та детально з'ясовано сутність і особливості цивільної, адміністративної та кримінальної відповідальності. Визначено діяння, за які наступає цивільна, адміністра тивна та кримінальна відповідальність. Досліджено підстави для притягнення до юридичної відповідальності за порушення авторських та суміжних прав.

3'ясовано, що найсуворішим видом юридичної відповідальності за порушення авторських і суміжних прав $є$ кримінальна відповідальність, яка настає за шкоду, завдану у значному, великому чи в особливо великому розмірі, встановленому законом, або у разі, якщо злочин вчинено повторно чи з використанням службового становища. Наведено пропозиції щодо удосконалення захисту прав на об'єкти інтелектуальної власності.

Ключові слова: інтелектуальна власність, суб'єкти права інтелектуальної власності, об'єкти права інтелектуальної власності, відповідальність за порушення авторських та суміжних прав.

В статье определены виды юридической ответственности и подробно определены сущность и особенности гражданской, административной и уголовной ответственности. Определены деяния, за которые наступает гражданская, административная и уголовная ответственность. Исследованы основания для привлечения $к$ юридической ответственности за нарушение авторских и смежных прав.

Выяснено, что самым строгим видом юридической ответственности за нарушение авторских и смежных прав является уголовная ответственность, которая наступает за ущерб, причинённый в значительном, крупном или в особо крупном размере, установленном законом, или в случае, если преступление совершено повторно или с использованием служебного положения. Приведены предложения по совершенствованию защиты прав на объекты интеллектуальной собственности.

Ключевые слова: интеллектуальная собственность, субъекты права интеллектуальной собственности, объекты права интеллектуальной собственности, ответственность за нарушение авторских и смежных прав.

The article identifies subjects of intellectual property rights, objects of intellectual property. A list of copyright and related rights violations has been identified to give grounds for protecting such rights.

The types of legal liability have been identified and the nature and features of civil, administrative and criminal liability have been clarified. Actions that cause civil, administrative and criminal liability have been identified. The grounds for civil, administrative and criminal liability for infringement of copyright and related rights have been investigated.

The ways of civil protection of copyright, types of administrative penalties, as well as the sanctions applied to the offender for infringement of copyright and related rights are investigated.

Changes to the legislation on the implementation of certain provisions of the EU legislation in the field of intellectual property are analyzed.

Янішевська К. Д., Воронкова М. Ю., 2019
It has been identified that one of the most common dispute resolution procedures for an author's rights to a work is civil liability. The main sign of a civil offense is the damage to property and personal non-property relations of the subjects of law. The main purpose of such liability is to compensate for the damage caused.

It has been investigated that the administrative and legal protection of copyrights involves the consideration and resolution of disputes by the public administration. A peculiarity of administrative responsibility is the application of certain types of administrative penalties.

It has been found that the most serious form of legal liability for copyright and related rights infringement is criminal liability for damage caused to a large or particularly large extent by law, or in the case of repeated crime or through official misconduct.

Suggestions are made to improve the protection of intellectual property rights.

Key words: intellectual property, subjects of intellectual property rights, objects of intellectual property rights, infringement of copyright and related rights, responsibility for infringement of copyright and related rights.

Постановка проблеми та іï актуальність. Важливим питанням сьогодення, яке заслуговує на особливу увагу, $\epsilon$ порушення авторських і суміжних прав, а також порядок їх захисту. Юридична відповідальність, як загальновідомо, $\epsilon$ важливим засобом впливу на учасників правовідносин, у тому числі в сфері авторського права і суміжних прав. Так, у разі порушення авторських чи суміжних прав до правопорушника можуть бути застосовані різні засоби впливу, такі як штраф, обмеження певних прав чи благ. На законодавчому рівні чітко визначено перелік діянь, які $\epsilon$ підставою для притягнення особи до відповідальності. Вид та міра покарання залежить від тяжкості тих наслідків, які спричинені потерпілому.

Варто наголосити, що загалом питання відповідальності за порушення авторських і суміжних прав врегульовано на досить високому рівні. Так, останніми роками законодавство стосовно захисту авторських і суміжних прав зазнало суттєвих змін і наповнилося новим змістом, проте досі залишаються неврегульованими деякі базові питання, пов'язані з відповідальністю за порушення авторських і суміжних прав.

Аналіз останніх досліджень та публікацій. Питання відповідальності за порушення авторських і суміжних прав досліджувалося низкою відомих вітчизняних учених. Серед робіт із зазначеної теми можна назвати праці таких авторів, як П. Андрушко, В. Бєлєвцева, В. Гулькевич, М. Галянтич, І. Дзера, В. Ковальський, А. Коваль, О. Підопригора, О. Ришкова та інші. Основним надбанням цих робіт $\epsilon$ аналіз відповідальності за порушення прав інтелектуальної власності, в тому числі у сфері авторських і суміжних прав.

Метою статті $\epsilon$ сутність та характеристика різновидів відповідальності за порушення авторських і суміж- 
них прав, а також пропозиції щодо удосконалення захисту авторських і суміжних прав.

Виклад основного матеріалу. Результати інтелектуальної діяльності визначають подальший прогрес та економічний розвиток держави, а також рівень моральності суспільства. Так, розв'язання економічних проблем залежить від інтелектуального потенціалу суспільства та рівня його культурного розвитку. Розвиток культури та науки можливий лише за умови дієвого механізму захисту авторських і суміжних прав.

Відповідно до статті 41 Конституції України кожен має право володіти, користуватися та розпоряджатися своєю власністю, результатами своєї інтелектуальної, творчої діяльності [1]. Суб'єктами права інтелектуальної власності є: творець об'єкта права інтелектуальної власності (автор, виконавець, винахідник тощо) та інші особи, яким належать особисті немайнові та (або) майнові права інтелектуальної власності відповідно до цього Кодексу, іншого закону чи договору [4]. Об'єктами права інтелектуальної власності $\epsilon$ : літературні та художні твори; комп'ютерні програми; компіляції даних (бази даних); виконання; фонограми, відеограми, передачі (програми) організацій мовлення; наукові відкриття; винаходи, корисні моделі, промислові зразки; компонування напівпровідникових виробів; раціоналізаторські пропозиції; сорти рослин, породи тварин; комерційні (фірмові) найменування, торговельні марки (знаки для товарів і послуг), географічні зазначення; комерційні таємниці [4].

Питання щодо створення і використання об'єктів права інтелектуальної власності регулюються Цивільним кодексом України, законами України «Про авторське право і суміжні права», «Про охорону прав на знаки для товарів іпослуг», «Про охоронуправ навинаходи ікорисні моделі», «Про охорону прав на промислові зразки», «Про розповсюдження примірників аудіовізуальних творів, фонограм, відеограм, комп'ютерних програм, баз даних» та іншими нормативно-правовими актами.

Законом України «Про авторське право і суміжні права» визначено перелік порушень авторського права i суміжних прав, що дає підстави для захисту таких прав, а саме: 1) вчинення будь-яких дій, які порушують особисті немайнові права суб'єктів авторського права і (або) суміжних прав та їхні майнові права, а також зловживання посадовими особами організації колективного управління службовим становищем, що призвело до невиплати або неналежних розподілу i виплати винагороди правовласникам; 2) піратство у сфері авторського права і (або) суміжних прав, тобто опублікування, відтворення, ввезення на митну територію України, вивезення з митної території України i розповсюдження контрафактних примірників творів (у тому числі комп'ютерних програм і баз даних), фонограм, відеограм, незаконне оприлюднення програм організацій мовлення, камкординг, кардшейрінг, а також інтернет-піратство; 3) плагіат - оприлюднення (опублікування), повністю або частково, чужого твору під іменем особи, яка не $\epsilon$ автором цього твору; 4) ввезення на митну територію України без дозволу осіб, які мають авторське право і (або) суміжні права, примірників творів (у тому числі комп'ютерних програм i баз даних), фонограм, відеограм, програм мовлення; 5) вчинення дій, що створюють загрозу порушення авторського права і (або) суміжних прав; 6) будь-які дії для свідомого обходу технічних засобів захисту авторського права і (або) суміжних прав, зокрема виготовлення, розповсюдження, ввезення з метою розповсюдження i застосування засобів для такого обходу; 7) підроблення, зміна чи вилучення інформації, зокрема в електронній формі, про управління правами без дозволу суб'єктів авторського права і (або) суміжних прав чи особи, яка здійснює таке управління; 8) розповсюдження, ввезення на митну територію України з метою розповсюдження, публічне сповіщення об'єктів авторського права і (або) суміжних прав, з яких без дозволу суб'єктів авторського права і (або) суміжних прав вилучена чи змінена інформація про управління правами, зокрема в електронній формі; 9) камкординг, кардшейрінг [4].

Важливо зазначити, що чинне законодавство України передбачає адміністративну, цивільну та кримінальну відповідальність за порушення авторських і суміжних прав.

Найбільш поширеною процедурою вирішення спорів щодо прав автора на твір $\epsilon$ цивільно-правова відповідальність. Головною ознакою цивільного правопорушення $\epsilon$ те, що внаслідок суспільно шкідливого, протиправного діяння спричиняється шкода майновим і особистим немайновим відносинам суб'єктів права. Основна мета такої відповідальності - не покарання за недотримання встановленого правопорядку, а відшкодування заподіяної шкоди. Особливостями цивільно-правової відповідальності $\epsilon$ : майновий характер; компенсаційний характер; відшкодування моральної шкоди [7, с. 54].

Варто наголосити, що у цивілістичній доктрині простежуються різні погляди щодо сутності цивільно-правової відповідальності. На думку Р.Б. Шишки, цивільна відповідальність проявляється у примусовому позбавленні порушника певних належних йому цінностей на основі рішення суду [8, с. 168]. В.В. Луць розглядає цивільно-правову відповідальність «як різновид санкції - покладення на правопорушника основаних на законі невигідних правових наслідків, які виявляються у позбавленні його певних прав або в заміні невиконаного обов'язку новим, або у приєднанні до невиконаного обов' язку нового додаткового» [6, с. 695]. Ми цілком підтримуємо думки зазначених вище учених щодо сутності цивільно-правової відповідальності та хочемо додати, що цивільно-правова відповідальність відрізняється компенсаційним та попереджувальним характером.

Вважаємо за доцільне звернути увагу на цивільно-правові способи захисту у разі виявлення порушення авторських чи суміжних прав. Так, відповідно до статті 52 Закону України «Про авторське право і суміжні права» передбачено, що у разі порушень будь-якою особою авторського права або суміжних прав, недотримання передбачених договором умов використання творів і об'єктів суміжних прав, порушень особистих немайнових прав і майнових прав суб'єктів авторського права і суміжних прав вони мають право: вимагати визнання та поновлення своїх прав, у тому числі заборону дії, що порушує авторське право чи створює загрозу його порушення; звернення до суду з позовом про поновлення порушених прав та (або) припинення дій, що порушують авторське право чи створюють загрозу його порушення; подання позову про відшкодування моральної (немайнової) шкоди; подання позову про відшкодування збит- 
ків (матеріальної шкоди), включаючи упущену вигоду, або стягнення доходу, отриманого порушником внаслідок порушення ним авторського права, або виплату компенсацій [5].

Наступним видом юридичної відповідальності за порушення авторських і суміжних прав $\epsilon$ адміністративна відповідальність.

Адміністративний спосіб захисту авторського права полягає у розгляді і вирішенні спорів органом державного управління. Процедура вирішення спору $\epsilon$ необтяжливою, на відміну від цивільного способу. Правовою основою $€$ Кодекс України про адміністративні правопорушення, а також закони України «Про авторське право і суміжні права», «Про охорону прав на винаходи і корисні моделі» та інші нормативно-правові акти. Підставою для притягнення до адміністративної відповідальності $\epsilon$ адміністративний проступок. Особливістю адміністративної відповідальності $\epsilon$ те, що до правопорушника застосовуються певні види адміністративних стягнень. Ці стягнення є специфічними за змістом і відрізняються від заходів кримінального дисциплінарного та майнового впливу.

Статтею 51-2 Кодексу України про адміністративні правопорушення передбачено відповідальність за незаконне використання права інтелектуальної власності, зокрема авторських і суміжних прав (на літературний чи художній твір, його виконання, фонограму, передачу організації мовлення, комп'ютерну програму, базу даних), привласнення авторства на один з перелічених об'єктів або інше умисне порушення прав на об'єкт, який охороняє закон. Санкція статті 51-2 КУпАП передбачає штраф у розмірі від 10 до 200 неоподатковуваних мінімумів доходів громадян з конфіскацією незаконно виготовленої продукції, обладнання та матеріалів, які призначені для її виготовлення [2].

Відповідно до статті 164-7 Кодексу України про адміністративні правопорушення розповсюдження і демонстрування фільмів з порушенням умов, передбачених державним посвідченням на право розповсюдження i демонстрування фільмів, тягне за собою накладення штрафуврозмірівід20до35неоподатковуванихмінімумів доходів громадян з конфіскацією фільмокопій, а також грошей, отриманих від їх демонстрування, продажу або передачі у прокат. Штраф у розмірі від 35 до 70 неоподатковуваних мінімумів доходів громадян стягується у разі вчинення цих дій повторно протягом року після застосування заходів адміністративного стягнення [2].

Таким чином, адміністративний захист авторського права і суміжних прав - це система адміністративних заходів, які застосовують уповноважені органи державної влади з метою відновлення, визнання прав, припинення порушень авторських і суміжних прав та притягнення винних осіб до відповідальності.

Найсуворішим видом юридичної відповідальності за порушення авторських і суміжних прав $є$ кримінальна відповідальність.

За порушення авторських прав, зокрема у разі, коли правоволодільцю завдано матеріальної шкоди у значному, великому чи в особливо великому розмірі, встановленому законом, або у разі, якщо злочин вчинено повторно чи з використанням службового становища, то настає кримінальна відповідальність.

Питання кримінальної відповідальності за порушення авторських і суміжних прав регламентується Криміналь- ним кодексом України, який, на превеликий жаль, не містить окремого розділу про злочини, пов'язані з використанням об'єктів авторського права і суміжних прав.

Так, згідно зі статтею 176 Кримінального кодексу України кримінально караним визначається умисне незаконне відтворення, розповсюдження творів науки, літератури і мистецтва, комп'ютерних програм і баз даних, а так само незаконне відтворення, розповсюдження виконань, фонограм, відеограм і програм мовлення, їх незаконне тиражування та розповсюдження на аудіо- та відеокасетах, дискетах, інших носіях інформації, камкординг, кардшейрінг або інше умисне порушення авторського права і суміжних прав, а також фінансування таких дій, якщо це завдало матеріальної шкоди у значному, великому або в особливо великому розмірі. Санкція статті 176 КК України передбачає покарання у вигляді штрафу, виправних робіт, позбавлення волі, а також позбавлення права обіймати певні посади чи займатися певною діяльністю [3].

Варто зазначити, що притягнути порушника до кримінальної відповідальності можливо лише за позовом особи, авторські чи суміжні права якої порушено. Таким чином, потерпіла особа має звернутись із позовом до суду із підтверджуючими документами, які мають містити інформацію про порушення її авторських чи суміжних прав.

Також Кримінальний кодекс України містить статтю 203-1, яка передбачає відповідальність за незаконне виробництво, експорт, імпорт, зберігання, реалізацію та переміщення дисків для лазерних систем зчитування, матриць, обладнання та сировини для їх виробництва, якщо ці дії вчинені у значних та великих розмірах. Максимальний розмір штрафу за вчинення зазначених вище дій становить десять тисяч неоподатковуваних мінімумів доходів громадян.

Статтею 216 КК України передбачена відповідальність за незаконне виготовлення, підроблення, використання або збут незаконно виготовлених, одержаних чи підроблених контрольних марок для маркування упаковок примірників аудіовізуальних творів, фонограм, відеограм, комп'ютерних програм, баз даних чи голографічних захисних елементів. Санкція статті 216 КК України передбачає накладення штрафу, максимальний розмір якого не може перевищувати п'яти тисяч неоподатковуваних мінімумів доходів громадян [3].

Отже, вищевикладене дає підстави дійти висновку, що цивільна, адміністративна та кримінальна відповідальність не можуть повною мірою забезпечити надійний та ефективний захист авторського та суміжного права, а тому $\epsilon$ необхідність посилити вищезазначені види юридичної відповідальності. Нині Верховна Рада України здійснила певні позитивні кроки в цьому напрямі, зокрема зареєстрована нова редакція Закону «Про авторське право і суміжні права» № 10143 від 12.03.2019 [9]. Проєкт Закону передбачає посилення відповідальності за порушення прав на об'єкт права інтелектуальної власності, а також удосконалення норм щодо захисту авторського права та суміжних прав у судах. Зазначені зміни насамперед зумовлені необхідністю боротьби із посяганням на об'єкти права інтелектуальної власності та плагіатом, а також приведенням національного законодавства у відповідність до взятих Україною перед Світовою організацією торгівлі та ЄС зобов'язань у сфері інтелектуальної власності. 
Крім того, проєкт Закону передбачає внесення змін до статті 176 Кримінального кодексу України 3 метою підвищення суми штрафів, установивши їх у межах від 300 до 1000 неоподатковуваних мінімумів доходів громадян, а також передбачення виправних робіт на строк до двох років чи позбавлення волі на той самий строк. Також проєктом планується внести зміни до статей 51-2, 164-9 Кодексу України про адміністративні правопорушення з метою збільшення розміру штрафів [9].

Висновки. Отже, в Україні діє сучасна законодавча база щодо захисту авторських і суміжних прав. За порушення авторських та суміжних прав може настати цивільна, адміністративна або кримінальна відповідальність. Для України характерним на цьому етапі $\epsilon$ те, що значна частина порушень авторських та суміжних прав і межі відповідальності за ці порушення вирішуються в судовому порядку. На нашу думку, крім судового захисту, в Україні потрібно розвивати практику самозахисту авторських прав, оскільки це сприятиме настанню позитивних наслідків, а саме зменшиться кількість судових справ та пришвидшиться процес розв'язання конфліктів, оскільки така вимога буде направлятися безпосередньо порушнику.

Нині $\epsilon$ необхідність подальшого вдосконалення правового регулювання відповідальності за порушення авторських та суміжних прав. Прикладом перспективних напрямів удосконалення захисту в зазначеній сфері $\epsilon$ прийняття нової редакції Закону України «Про авторське право і суміжні права», а також посилення цивільної, адміністративної та кримінальної відповідальності. Зазначені зміни допоможуть вдосконалити законодавство у сфері захисту авторських і суміжних прав, запровадити дієві механізми посилення охорони та захисту прав та інтересів суб'єктів авторського права і суміжних прав, а також наблизити національне законодавство до норм Європейського Союзу.

\section{Література}

1. Конституція України : Закон України від 28.06.1996 № 254к/96-BP. / Верховна Рада України. URL: https: / /zakon. rada.gov.ua/laws/show/254\%D0\%BA/96-D0\%B2\%D1\%80.

2. Кодекс України про адміністративні правопорушення від 07.12.1984 № 8073-X. URL: https://zakon.rada.gov.ua/ laws/main/80731-10.

3. Кримінальний кодекс України від 05.04.2001 №2341-III.URL:https: / / zakon.rada.gov.ua/laws/show/2341-14/ ed20150308.

4. Цивільнийкодекс Українивід 16.01.2003 № 435-IV. URL: https://zakon.rada.gov.ua/laws/show/435-15/ed20130609.

5. Про авторське право і суміжні права : Закон України від 23.12.1993 № 3792-XII. URL: https://zakon.rada.gov.ua/ laws/show/3792-12.

6. Дзера О.В. Цивільне право України: в 2 т. / О.В. Дзера, Д.В. Боброва, А.С. Довгерт та ін. 2-ге вид., допов. і переробл. Київ : Юрінком Інтер, 2004. Кн. 1. 736 с.

7. Підопригора О.А., Мельник М.Г. Мельник О.М. Право інтелектуальної власності в Цивільному кодексі України. Цивільний кодекс України. Міркування з окремих проблем застосування. Науковий збірник. Київ : Слово, 2005. 368 с.

8. Шишка Р.Б. Цивільне право України. Особлива частина : підручник / за заг. ред. д.ю.н., проф. Р.Б. Шишки. Київ : Вид. Ліра-К, 2015. 1024 с.

9. Проєкт Закону про авторське право і суміжні права № 10143 від 12.03.2019. URL: http://search.ligazakon. ua/l_doc2.nsf/link1/JH7TR00A.html.

Янішевська К. Д., кандидат юридичних наук, старший викладач кафедри кримінально-правових дисциплін та судочинства Навчально-наукового інституту права Сумського державного університету

Воронкова М. Ю., магістрант 2 року навчання Навчально-наукового інституту права Сумського державного університету 